\title{
Challenges Faced in the Implementation of the Zimbabwe Agenda for Sustainable Socio-Economic Transformation Economic Policy from 2013 to 2018
}

\author{
Patricia Masiyakurima $^{1}$, Alouis Chilunjika ${ }^{1}$, Sharon Muzvidziwa-Chilunjika ${ }^{1}$ \\ ${ }^{1}$ Department of Politics and Public Management, Midlands State University. \\ Zvishavane, Zimbabwe.
}

Article History

Received:

28.09.2020

Revised:

24.11.2020

Accepted:

04.12 .2020

*Corresponding Author:

Alouis Chilunjika

Email:

chilunjikaa@staff.msu.ac.zw

This is an open access article, licensed under: $\mathrm{CC}-\mathrm{BY}-\mathrm{SA}$

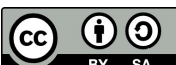

Abstract: A number of policies have been put in place as of 1980 but the implementation of the policy objectives has been highly compromised. This research is therefore premised on exploring the challenges faced in the implementation of economic policies using the Zimbabwe Agenda for Sustainable Socio-Economic Transformation (ZIMASSET) of 2013 to 2018 as the focal point. The study employs a case study research design which triangulates qualitative as well as quantitative research methods into mixed methods. On sampling techniques, the research employs simple random sampling and purposive sampling. Structured questionnaires and in-depth interviews were also used in collecting data. The research established that the ZIMASSET policy has been ruled out as an appetizing economic blueprint which when followed to its logical conclusions can in a way turn around the economic fortunes of the country. Be that as it may, some contend that there is nothing peculiar about the ZIMASSET policy as it is yet another attempt by the ZANU-PF led government to moot a policy that will die a premature death. In light of this, the study recommends policy autonomy, multiplicity of sources of funding, supporting the agricultural sector, curbing corruption, clear policy procedures as well as utmost commitment to the policy as strategies that can enhance the successful implementation of future economic policies in Zimbabwe.

Keywords: Economic Policies, Government, Public Policy, ZIMASSET. 


\section{Introduction}

A number of policies have been brought forward in Zimbabwe as an important role of the Government. From 1980, Zimbabwe saw the adoption of economic policies meant to re-integrate the formerly marginalized black majority into a white dominated economic mainstream [1]. The majority of the policies that were adopted were aimed at addressing social ills through poverty eradication and general improvement of living standards. From 1980 the country embarked on what can basically be known as post war reconstruction with the support of foreign donors, recapitalization and admission into the world economy.

Lack of prudent management, corruption, and support among other issues cannot be divorced from the policies instituted in Zimbabwe hence the rapid need for policy shift and re-orientation. The ZIMASSET is a policy that has been adopted in Zimbabwe to revive the economy from the economic doldrums. Be that as it may, the austerity plan has not yet delivered due to one reason or the other. The policy seeks to leverage both human and natural resources for a transformed economy but this has not been the case. The economy is deteriorating instead of improving. Furthermore, the 2.2 million jobs that were to be created are nowhere to be found and the country has been turned into a street economy using more of plastic money due to cash crisis.

Furthermore, the policy had an intention to revive industries but to date a number of industries have either downsized or closed. In as much as the policy seeks to attract Foreign Direct Investment, there has been massive exodus of the foreign investment. Corruption has been so lethal and has suffocated the possible hopes for the implementation of the policy. Therefore, given this end, the researcher made a detailed analysis of the challenges faced in the implementation of policies in Zimbabwe.

\section{Literature Review}

Various theories inform the challenges faced in the implementation of economic policies in Zimbabwe. Therefore, the topic under study has been explored from a wide range of theories. Of interest to the researcher is the Elitist theory. This theory shall therefore be examined in relation to the topic and its utility established thereof.

\subsection{Elitist Theory}

The Elite theory trusts that well of elites are in charge of the everyday running of the country. The political first class is consequently comprised of important office bearers. Therefore, the elites make important decisions on behalf of the rest of the citizenry. This was the case with the ZIMASSET, whereby the political first class of ZANU PF came up with a political manifesto that was sneaked into the national policy bank without consultation. In elitism, the interests of the political first class are served. Juxtaposing this submission to the ZIMASSET, it is apparent that the policy has only been beneficial to the ZANU PF party.

Exemplified is the Presidential Input Support Scheme which has only been beneficial to the party members and distributed on a political podium. Elitism as a theory dismisses the efficacy of consultation. In respect of the ZIMASSET, there was absence of consultation since the policy emanated from the ZANU PF technocrats without consultation.

\subsection{Experiences in Selected Countries}

The need for economic policies is not much of a novelty for Zimbabwe as other countries as well have come up with economic policies to bankroll their economies. The research shall allude to three different countries and their experiences in the implementation of economic policies. China, Namibia and South Africa are the three countries that shall be made reference to in relation to the topic under study.

\subsubsection{China's Experience}

Pham (2018) highlights that China's economy has been growing more than any country due to a cocktail of reasons. A huge population in China, production efficiency and intensity and capital are some of the important contributing factors to the development of China's economy [2]. Furthermore, modern technology has allowed China to be economically successful. China has implemented an open door and reform policy and has since experienced rapid productivity. China learnt from the West and 
it has been profitable for her. Good governance explains China's economic success from a separate angle.

The commitment and schedules of the government are quite commendable. The government has done lots in the transformation of a communist state to an open, economic driven nation successfully. Development policies such as special economic zones and economic development guidelines have been put in place.

However, some critics are of the view that the government of China has attracted delinquencies such as corruption, pollution, inefficiency in allocating resources and this disfavour economic growth. The same has been testified in the Zimbabwean context. Corruption sits at the heart of the economic problems in this country together with other factors [3]. Stringent measures against this anomaly with therefore set the economy free coupled with government's unlevelled commitment.

\subsubsection{Namibia's Experience}

Namibia's economy has thrived since its independence due to a combination of a number of factors. Namibia's economy is composed of a traditional subsistence sector and a modern market. This enables economic stability for Namibia. Skilled workers and a huge number of professionals aid the economic stability of the country. The Gross Domestic Product (GDP) of Namibia stands at US\$5,828 though it is earmarked by gross inequalities in terms of income distribution and the general standards of living.

From independence, Namibia has pursued policy programmes meant to engage the once segregated Namibians into the economic mainstream. The government had to court donor funding and also foreign investment. To this effect, Namibia is undertaking a pragmatic agrarian reform so as to turn the economic fortunes of the country. Zimbabwe undertook the same process in reforming the land question. Namibia's economy is not necessarily monolithic. The country centres on capital intensive industry and farming.

Furthermore, Lange [4] highlights that there is dependency on income commodities such as fish, livestock, and mineral resources such as diamonds. Namibia's economic story is explainable in South African terms as most of the imports come from there. Namibia as a country is strategically located as a communication and transport base in facilitating regional economic integration. Namibia has membership in both Southern African Customs Union (SACU) and Southern African Development Community (SADC). An estimate of 13.9 billion revenue is received by Namibia from SACU. Privatization of enterprises allowed growth of foreign investment though the move was not welcome for trade unionists.

\subsubsection{South Africa's Experience}

Since Apartheid, the economy of South Africa has remarkably improved. The formal economy of South Africa can be traced as far as 1652 with the arrival of Dutch settlers, French and consequently the British. The discovery of diamonds in Kimberly transformed the economy into a resource dominated economy. The country experienced rapid industrialization and laws became selectively applicable along racial lines.

In 1994, African National Congress (ANC) won the elections and put in place policies meant to grow the economy. Attempts on land redistribution were made with the government aiming to transfer $30 \%$ of the 82 million hectares presumed to be in the hands of the white farmers. In respect of this, South Africa stands second to Nigeria as the largest economy in the whole of Africa and qualifies as an upper middle- income economy [5]. Be that as it may, a number of factors have militated against a robust economic growth in South Africa. Among other factors, there is shortage of skilled personnel, inefficiency in governance, corruption and also political volatility. South Africa's liberal economic policy has turn around the economic fortunes of the country through an open door policy.

\section{Methodology}

This article analyses the challenges faced in the implementation of economic policies in Zimbabwe. This entails analysing the need for economic policies in Zimbabwe, the legal and institutional framework surrounding the policy, factors leading to the crafting of the policy and challenges faced in their implementation thereof.

The article therefore raises these questions: 
- Why are economic policies needed in Zimbabwe?

- What are the factors that led to the crafting of the ZIMASSET policy in Zimbabwe?

- What are the key institutional and legislative frameworks that support the implementation of the ZIMASSET policy?

- What are the challenges faced in the implementation of the ZIMASSET?

- What measures can be put in place to ensure the successful implementation of the ZIMASSET policy in Zimbabwe?

Data collection combined documentary and field research. Documentary research entailed extensive review of the ZIMASSET document, newspaper articles, academic and professional journals. There was also use of electronic media in the form of internet sites, that is, e-library where journals, books, articles, magazines and other corpus of material online in soft copy format. Field research entailed use of face-to-face interviews, questionnaires, direct observation and documentary research and in this way enabled triangulation.

Questionnaires used open and closed-ended questions to solicit for responses from targeted respondents. Out of the 43 questionnaires that were administered to respondents from government ministries that inform the ZIMASSET, economists, farmers, miners among others, all of them were returned, indicating a $100 \%$ response rate. Questionnaires gathered data on issues such as the factors leading to the crafting of the ZIMASSET policy in Zimbabwe, institutional and legal framework governing the ZIMASSET, challenges faced in the implementation as well as recommendations. Complementing the questionnaires were in-depth face-to-face interviews with sampled individuals assumed to be well informed and educated in the subject of policies specifically the ZIMASSET.

The researcher set out the criteria for the respondents to be incorporated into the research; subsequently, whoever met the criteria was chosen in the research under purposive testing. Castillo [6] characterized purposive inspecting as a non - likelihood examining procedure where the researcher chooses units to be tested dependent on their insight and expert judgment. The respondents were selected on the basis of their knowledge of the ZIMASSET policy. Using the adopted purposive sampling framework, the researcher used Manicaland Province for the sake of research convenience.

Collated data was analysed using the Statistical Package for Social Sciences (SPSS) which allows the quantitative analysis of data. The SPSS package enabled the researcher to determine frequencies in various responses to research questions. Content analysis was also employed in this study as well. Data presentation entailed use of graphs, tables as well as pie charts.

\section{Finding and Discussion}

\subsection{Age}

From Table 1, male participation was pegged at $37.20 \%$ as compared to females who amassed a $62.26 \%$. With regard to the utility of the gender response rate to the research is clear that participation of women increased due to empowerment. Furthermore, the agony of women was too much as the policies are not catering for their maternal and reproductive health to their expectations.

Table 1. Gender

\begin{tabular}{ccc}
\hline Participants & Frequency & Percentage \\
\hline Males & 27 & $37.20 \%$ \\
\hline Females & 16 & $62.26 \%$ \\
\hline Total & $\mathbf{4 3}$ & $\mathbf{1 0 0 \%}$ \\
\hline
\end{tabular}

On the notion of age response rate, youths participated more in the research. From the pie chart youths constituted $74.41 \%$ of the total research population. The outstanding participation of youths is basically explained by the fact that the country has a more youthful population. Furthermore, youths are an important group and they contribute to a country's economic development. The ZIMASSET policy promised 2.2 million jobs through opening up industries among other promises that were never fulfilled and these are the situations that the youths are grappling with daily. 


\section{Age Patterns}

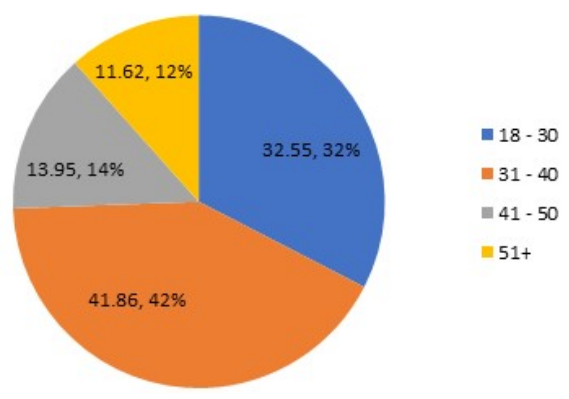

Figure 1. Age Patterns

\subsection{Sample Response Rate}

From the data distilled from the respondents through interviews and questionnaires, economic policies are a requisite in Zimbabwe in as far as national development is concerned. The table above shows a $100 \%$ response rate in support of the essence of economic policies in Zimbabwe.

Table 2. The Essence of Economic Policies in Zimbabwe

\begin{tabular}{cc}
\hline Statement & Response Rate in Percentage \\
\hline Employment Creation & 100 \\
\hline Sanction Basting Strategy & 100 \\
\hline Economic Efficiency & 100 \\
\hline To reduce poverty levels & 100 \\
\hline Infrastructural Development & 100 \\
\hline
\end{tabular}

This view coincides with what Plosila [7] highlights on the need for economic policies predicated upon development. The justification of economic policies lies in the need to increase the rhythm of the economy. Zimbabwe inherited a colonial government with the economic development clearly upon racial grounds. However, the government had to come up with austerity plans that are redistributive in nature. Furthermore, economic policies are much needed in Zimbabwe with the view to reduce poverty and its debilitating effects, joblessness, infrastructural problems and nutrition issues among other detrimental issues.

In the same vein, a number of economic policies have been mooted in Zimbabwe but still these policies have not turn around the economic fortunes of the country. However, this can be explained by a multiplicity of factors. From the data obtained from the respondents, various sentiments were surfaced on the rationale of economic policies in Zimbabwe. 30\% of the respondents remarked that there is no rationale for the economic policies in Zimbabwe because they are never implemented.

The ZIMASSET is just another policy that as usual will not be implemented under any circumstance. Zimbabwe has had a history of crafting economic blueprints which are meant to improve the economy of the country and eradicate poverty and ensure creation of jobs but most of them fail at implementation stage. On the contrary, another respondent argued that, the rationale of economic policies in Zimbabwe lies in the need to stabilize economy, ensuring economic growth (GDP): Improve the standards of living, create employment as well develop the infrastructure. The highlighted responses reveal that policies are necessary in Zimbabwe though they lack on the implementation and this weakens the economy. For Kangwari [8], the four - legged ZIMASSET economic blue print is the latest one to be formulated by the government of Zimbabwe after a host of other policies have not yielded any results due to a reason or the other. Poor budgeting and inadequate policy education are some of the myriad of reasons that undermine the rationale of economic policies in Zimbabwe.

Table 2 suffices the need for economic policies in Zimbabwe. From the table, it is instructive to assert that the ZIMASSET policy exists to create employment, to ensure economic efficiency, reduce 
poverty levels, infrastructural development as well as sustainability against the sanctions imposed by the West. $100 \%$ of the respondents submitted that, economic policies exist to improve the welfare of the populace. Give the populace a chance for a better life, reduce poverty and improve productivity in the country at the same time creating the necessary infrastructure for efficiency in business." This bears testimony on the need for economic policies in Zimbabwe.

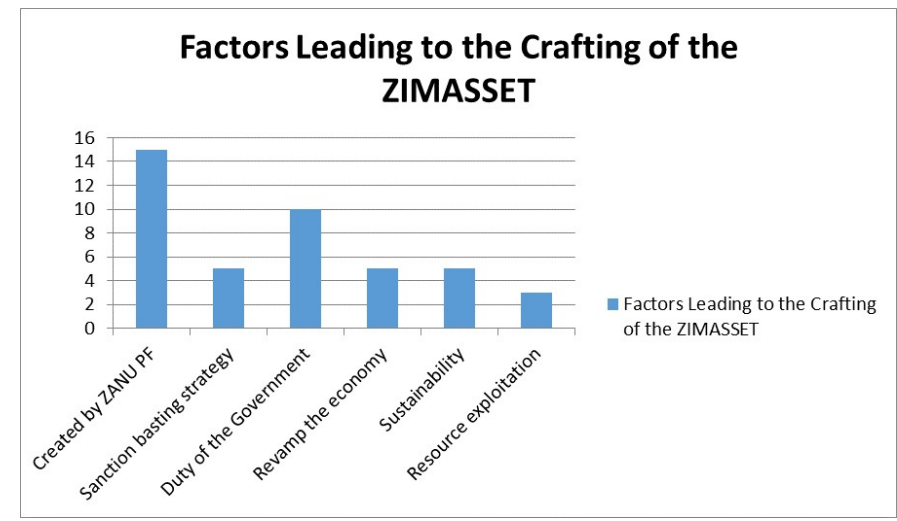

Figure 2. Factors Leading to the Crafting of the ZIMASSET

The study established that the ZIMASSET policy came into picture surrounded by a plethora of political, economic and social dimensional factors. The bar graph above summarizes the multidimensional approach to the factors leading to the crafting of the ZIMASSET policy which shall be explained thereof. The study alludes that a myriad of reasons exists in as much as the crafting of policies is concerned. The blueprint was arguably a ZANU PF party manifesto for the 2013 elections that was sneaked to be a national policy.

From the bar graph, eighteen out of forty-three respondents indicated that the policy was a ZANU $\mathrm{PF}$ party manifesto. Be that as it may, the ZIMASSET cannot be divorced from the economic sanctions imposed by the West. The policy therefore stood as a sanction busting strategy against deep economic and social crisis characterised by hyperinflation, poverty, unemployment, poor health facilities and redundant industrial capacity among other fundamentals. In respect of the factors leading to the crafting of the ZIMASSET, the research captured that the policy came into force as a result of the need to pardon the economy of Zimbabwe from doldrums, hence the government came up with the ZIMASSET." The view by respondent D corresponds with the submission made by Sibanda \& Makwata [1] as presented in the second section of this research. Five people indicated that the ZIMASSET was put in place to revamp the economy. They highlighted that the general reason behind the policies mooted in Zimbabwe as of 1980 were efforts to remove the economy from doldrums.

From the research findings, the government has a duty to come up with an economic policy that will govern the general functioning of the country. Therefore, the reason for the crafting of the ZIMASSET lies in the fact the government has an obligation to do so. The views is therefore in conformity with what is indicated in second section of the research through the Stanford Encyclopaedia [9]. The point of convergence comes when the mentioned scholar submits that the government is an important institution with the mandate to ensure quality living standards of its people through coming up with policies. Therefore, it is instructive that the government has a mandate to come up with economic policies hence leading to the crafting of the ZIMASSET policy. The following bar graph dissects the factors leading to the crafting of the ZIMASSET according to the responses attained in the field.

\subsection{Frameworks Governing Implementation of ZIMASSET Institutional Framework Governing the Implementation of the ZIMASSET}

A number of institutions exist in as much as the ZIMASSET is concerned. According to the ZIMASSET document [10], in an effort to engender team spirit in the operation of Government, 
Ministries and Government Agencies were put into clusters. These clusters are called upon to eliminate compartmentalization and the silo mentality by creating strong synergistic relationships that fully exploit the benefits of both horizontal and vertical linkages as a way of institutionalising harmonised approaches to Government Programming. The government is an important institution in policy making [9]. The ZIMASSET policy is arguably a creation of the government of Zimbabwe to chart a way around the economy of the country for its turnaround.

Furthermore, various line ministries form an important institution in the policy business of the country. The Ministry of Finance, Social Welfare, Tourism, Roads, Health, Energy, Mining, and Education are some of the ministries that have an important role in the implementation of the ZIMASSET. The ZIMASSET has four distinct clusters which impact differently on one ministry or the other. The various ministries that inform the ZIMASSET are many because it does not affect a specific ministry, this research delved on only two ministries as examples. The ministry of Finance is very important for budgeting purposes so that adequate financial and material resources are obtained in respect of the policy at hand.

More so, the Ministry of Agriculture is yet another important ministry which is important for the ZIMASSET policy. This ministry is important in ensuring that the ZIMASSET is fulfilled especially on the Food and Security cluster. However, the work of the Ministry remains highly compromised due to a reason or the other. Some respondents revealed that the Agricultural Sector was not fully funded except for those few individuals who received inputs through the Presidential Input Support Scheme and also the Command Agriculture Scheme. $70 \%$ of the respondents highlighted that, the centrality of the Ministry of Agriculture in the ZIMASSET remains uncontested though the Ministry did not do much and most farmers had to use their own means. Hence this shows that in as much as a number of ministries act as important institutions governing the implementation of the policy, their work has been compromised by one reason or the other.

Apart from that, the Private Sector is an important institution governing the implementation of the ZIMASSET. This sector mainly composed of Non- Governmental Organizations is important in coming up with activities that are in congruency with the country's national policy and contribute to developmental efforts. Non-Governmental Organizations which basically form the private sector formulates an important institution for the implementation of the policies. The activities of the private sector should ultimately feed into the policy bank of the country. Hence the activities should be complementary to the government efforts. Be that as it may, the ZIMASSET policy does not necessarily establish the centrality of the private sector in bankrolling the economy of the country.

The researcher captured the following response in light of the above nuanced point that, the ZIMASSET did not fortify the importance of the Private Sector and sometimes this sector does activities that do not necessarily contribute to the development of this country in any way. Furthermore, the citizenry forms an important institution for any policy hence they should be in possession of the policy so that implementation becomes easier. Apart from the citizenry, the Parliamentary Committee and the Executive form an important institution in the implementation of the ZIMASSET. It can also be argued that the parliament as a law-making body remains efficacious in debating policies brought forward before the adoption of the policy. Furthermore, the Office of the President and the Cabinet has an oversight, coordinative and policy guidance role in the implementation of a plan to be carried out through government ministries [10].

\subsection{The Key Legislative Framework Governing the Implementation of the ZIMASSET}

From the data collected from respondents, the legal framework of the ZIMASSET governs and regulates the policy. Furthermore, the World Law Dictionary [11] highlighted that the legislative framework regulates the agreements, decision making and also laws. From the data obtained through interviews and questionnaires, the relevant Acts of Parliament informs the ZIMASSET policy. The ZIMASSET goals are set within the legislative framework of the Indigenization and Economic Empowerment Act and should be developed in congruence with the corresponding ministries [12]. The guidelines and procedures for ensuring this indigenization are enshrined in the Chapter 14:33 of the Act and is directed by the Office of the President and the Cabinet. Line ministries therefore submitted their plans in line with the ZIMASSET goals.

Furthermore, the ZIMASSET policy clusters are informed by distinct frameworks. The ZIMASSET Document [10] reveals that the Food and Nutrition Cluster is informed by the Comprehensive African Agricultural Development Programme (CAADP), Draft Agriculture Policy 
Framework (2012 - 2032), the Food and Nutrition Security Policy, the Zimbabwe Agricultural Investment Plan (2013 - 2017), SADC, and COMESA Food and Nutrition Frameworks.

The Value Addition and Beneficiation cluster is informed by the Industrial Development policy, National Trade policy, National Tourism policy, Science and Technology and Innovation policy, Indigenization and Empowerment policy as well as Local Authority and National Licensing policy [10]. Therefore, the activities under this cluster are in consistency and cohesion with the aforementioned policies and the Constitution as well. However, from the data obtained from the field, the researcher observed that in as much as the frameworks for the ZIMASSET are clear, they remain theoretical.

Further, Masiyakurima [13] in substantiation of the argument posits that, the ZIMASSET is indeed a comprehensive and appetizing blueprint which has faltered on the implementation stage. The following respondent's views helps in concretizing this argument.

\subsection{A Snippet of the Achievements of the ZIMASSET Policy}

The study acknowledges that the ZIMASSSET policy like any other policies in Zimbabwe was not without its own problems. Be that as it may, the areas of success of the ZIMASSET policy were taken cognizance of. Agriculturally, the policy has been a noteworthy success. It is important to note that a number of farms within Manicaland Province are still thriving. Examples were inferred from Katiyo Tea Estate, Crake Valley Farm and the massive growth of macadamia nuts, bananas as well as maize within the region. These farms have in turn created employment for the few local people hence an important achievement. Furthermore, the expansion of energy has improved the livelihood of many households.

The Chisumbanje Ethanol Plant has created employment for a number of people in the encompassing zones. Other schemes such as Buwu mini hydro electrical schemes have been beneficial to the locals too. With regards to education, the Province remains the educational hub in respect of the quick aims of the ZIMASSET policy. Manicaland Province houses a number of schools that contribute largely to the literacy rate of the country as compared to the others.

The ZIMASSET aims to improve people's general living standards of the people and enhance their security. In line of this, the ZIMASSET has been successful on the notion of the provision of clean water to the citizens. Manicaland today has the safest water provision for its citizens. Road construction has been another remarkable benefit especially with reference to the Harare Mutare Road. However, from the snippet of achievements highlighted above it is quite manifest that the ZIMASSET's policy achievements are very meagre and not widespread.

\subsection{Challenges Faced In the Implementation of the ZIMASSET Policy}

Figure 3 shows the challenges faced in the implementation of the ZIMASSET.

\subsubsection{Corruption}

In capturing the challenges faced in the implementation of the ZIMASSET policy, the researcher obtained a cocktail of the challenges that were surfaced by the respondents from interviews as well as questionnaires.

The highest number of respondents who responded to questionnaires, that is 18 of the 43 respondents highlighted that corruption seats at the heart of economic problems in Zimbabwe since the phenomenon has failed a number of policies that were meant to turn around the economic fortunes of the country. It can be argued that corruption is an international problem which entails the systematic misdirection of funds in order to achieve personal gain [14].

More often than not, funds towards policies are gobbled and very little is left to ensure success of the policies brought forward. The problem of corruption is not only endemic to Zimbabwe but rife to a number of African countries.

Zimbabwe's corruption management is generally weak and most of the corruption cases are not thoroughly dealt with and in some cases ignored. Most parastatals and local authorities as the immediate stakeholders in disbursing economic policy goals are highly corrupt. This becomes a serious challenge which acts against the success of economic policies in Zimbabwe. Reference can be given to the fifteen billion dollars that went missing from the Chiadzwa Diamond Field. The amount would certainly carry the ZIMASSET halfway through. 


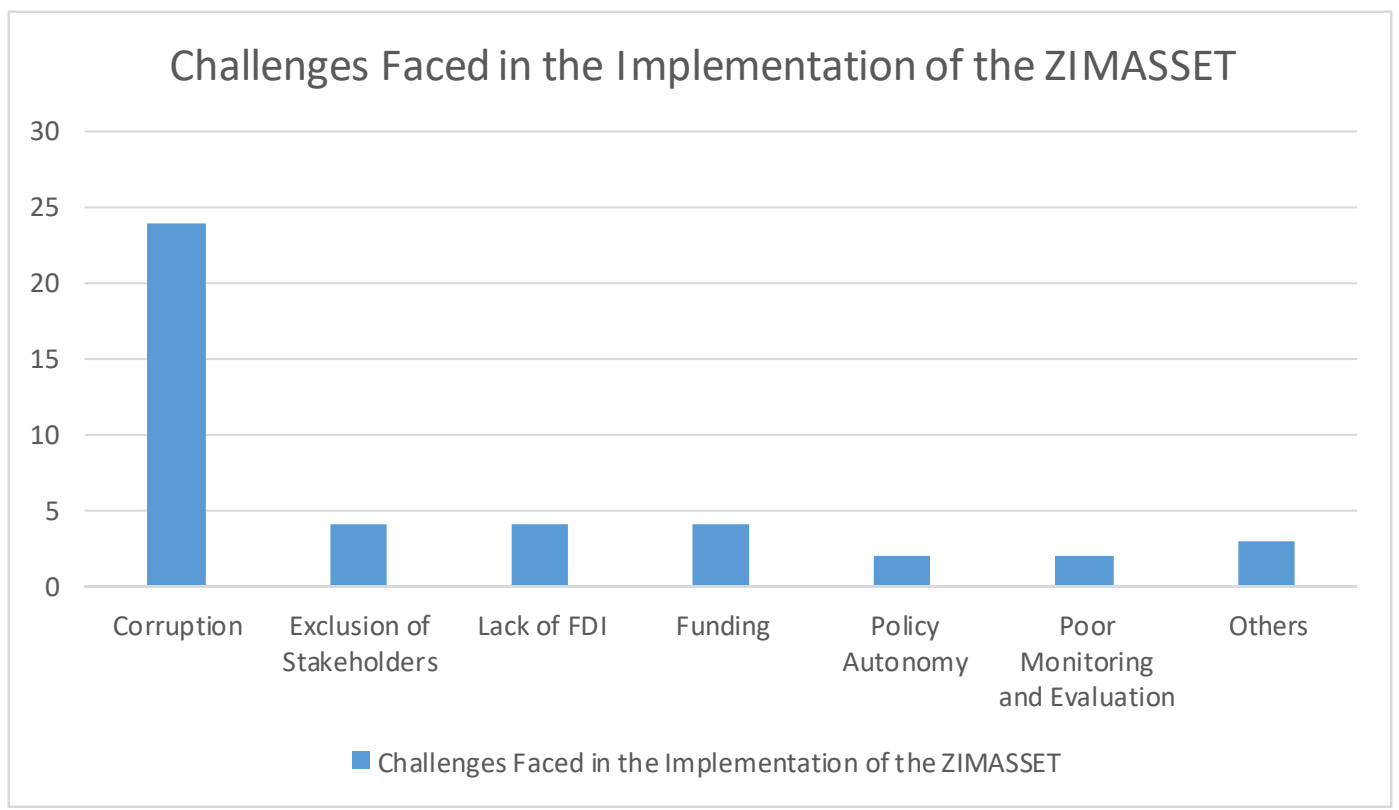

Figure 3. Challenges Faced in the Implementation of the ZIMASSET

4.6.2. Limited Time Frame

More so, the ZIMASSET was mooted in October 2013 and would run up to December 2018. This transcends to five years and given the policy objectives, it has been realised that the policy was accorded a limited timeframe of five years. The ZIMASSET is predicated upon four distinct clusters which need ample time to materialize.

Mujuru [15] argued that the policy was bankrupt on the time factor and will therefore fail to achieve its intended objectives. It is within this backdrop that indeed the ZIMASSET policy lacks on time hence a serious challenge. "In as much as the ZIMASSET is arguably a good blueprint which maps the way forward towards a robust economic growth through its four clusters, it is essential to note that a limited timeframe of five years has failed the policy. The policy has so much to be implemented within a limited space of five years."

However, in as much as the ZIMASSET was accorded a limited time frame as some respondents highlighted, it important to note that the ZIMASSET is challenged by a limited timeframe is quite fallacious. The five years were more than enough to realise policy goals. What they are now doing (the makers of the policy) is to pretend as if they may have made a late realization that the time was too limited. This has nothing to do with their failure otherwise they had ample time in the world."

\subsubsection{Multiplicity of Clusters}

In as much as the ZIMASSET is a boisterous economic policy with clear key focus areas, the clusters are so many to be realised in one goal. The wide range of clusters compromises the success of the policy. The limitedness nature of resources makes them insufficient to spread across every key result area of the policy.

The ZIMASSET is premised on four distinct clusters with broad and extensive focus areas [10]. These are Value Addition and Beneficiation, Social Service and Poverty Eradication, Food Security and Nutrition and Infrastructure and Utility. Furthermore, sub-clusters do exist within these main clusters. Scholars do aver that in order to bankroll the ZIMASSET, there is need to focus on mining industry and agriculture first and not the entire ZIMASSET policy. This transcend to the fact that the ZIMASSET is challenged by broad policy focus areas. $7 \%$ of the respondents submitted that, the ZIMASSET is a good economic blueprint which maps the way forward for a resuscitated economy. Be that as it may, the policy lacks on deliverables possibly due to too many clusters, people do not know about the policy, the policy is known by its creators and new policies are created every now and then. 


\subsubsection{Funding}

Apart from the above, the Zimbabwe Agenda for Sustainable Socio-Economic Transformation (ZIMASSET) requires 27 billion dollars for it to materialize. From the Literature Review, funding of policies is quite central so that all policy projects are implemented. The amount of funding and resources committed to an area directly affect development, quality and service to be obtained. In any case, it is very discouraging to take note of that the sum required to subsidize the ZIMASSET arrangement outperforms the country's spending plan notwithstanding when it is altogether collected for a long time. The yearly spending plan of Zimbabwe is 4.1 billion dollars and it is quite the decrease because of various variables. Fast conclusion of businesses, greater work in the casual segment henceforth diminished duty income, absence of Foreign Direct Investment (FDI), undercapacitation of the few existing enterprises because of the utilization of the surrogate money among different elements have made the economy excess.

The ZIMASSET blue print recognizes the presence of asset imperatives and demonstrates that the legislature subsequently needs to concoct a hearty and reasonable financial and money related arrangement estimates intended to brace and lift usage of the ZIMASSET. Subsidizing of the strategy will essentially originate from Sovereign Wealth Fund, impose and non - assess income, utilizing assets, issuance of securities, reengagement with the global and multilateral back organizations and examination of settlements.

All these highlighted sources have not contributed much to the fruition of the policy coupled with corruption hence a serious challenge. Furthermore, Lack of funding has also been detrimental to agricultural operations. Four respondents submitted that funding is a serious challenge for the ZIMASSET. Zimbabwe has an international debt of over US\$9 billion and also the domestic debt strips the Gross Domestic Product (GDP). Therefore, funding remains a serious issue in implementing the ZIMASSET policy.

Shumba [16] in respect of the above submission by Respondent $J$ asserts that Zimbabwe has scored a number of achievements under the ZIMASSET policy. The basis of the argument was that, among the key achievements was the ease of doing business reform process which resulted in a review of a number of investment laws, the success of the Command Agriculture for the food security cluster. Other achievements include the fruitful re-engagement with the international community and the Diaspora, adoption of special economic zones, signing of mega deals in the energy sector, infrastructure as well as introduction of electronic governance.

\subsubsection{The Absence of Policy Autonomy}

Besides funding as a challenge to the implementation of the ZIMASSET policy, there is absence of policy autonomy as was indicated by two respondents as indicated in the graph above during interviews with some respondents. Mpofu [17] opined that the policy is flawed as it was crafted during a period when there was too much of political tension and there was need to win the election in the face of opposition. Partisan politics has also resulted in incompetent people taking initiative in coming up with policies by virtue of them belonging to the ruling party. It is within this backdrop that the implementation of the ZIMASSET becomes compromised as it is divided across political lines. For the ZANU PF party, the policy dictates are being delivered but for other parties, the policy has not yet materialized. There is need for policy shift in Zimbabwe so that policies are implemented from a neutral basis.

The ZIMASSET came into effect as of October 2013 and on arguably partisan basis. The five-year financial policy was created after the avalanche triumph of the ZANU PF Party after the 2013 Presidential polls. The strategy cannot be isolated from ZANU PF. It is contended that the policy was removed from the ZANU PF party proclamation and it bleakly neglected to change the monetary beat of Zimbabwe. The nation's financial circumstance is wretchedly exacerbating. A huge number of youths and opposition members who participated in the research discredited the ZIMASSET for its failure to be neutral, to bankroll the economy of the country and at the same time failed to create the much-needed employment.

The ZIMASSET has been a tremendous failure as it has failed to create the much-needed employment and also open industries so that at least youths would work there and at least reduce the poverty levels. The policy lacked neutrality as benefits were extended to the party supporters. Machiva [18] posits that the ZIMASSET is an economic policy that is highly celebrated in the political front however with nothing much to offer to the economy. The ZIMASSET has too many 
clusters and what the ZANU PF just did was to identify the problems in the economy and set them as aims of the policy. Be that as it may, the majority of these have not been implemented.

Mhlanga [19] further cements that the ZANU PF as a party cannot be purely distilled from the state and the government. Quite recently, the party was enjoying an unfair advantage by abusing state resources during elections (Zimbabwe Elections Support Network). Food aid and agricultural inputs are not accorded freely whether from the state, or government. Hence it is within this background that lack of policy autonomy is a serious challenge militating against the success of the policy.

\subsubsection{Lack of Foreign Direct Investments}

In highlighting the challenges faced in the implementation of the ZIMASSET, lack of Foreign Direct Investment (FDI) was surfaced by four respondents as indicated in the graph. The ZIMASSET approach tries to use both characteristic and Human Resource supplied inside Zimbabwe with the end goal to draw in Foreign Direct Investment (FDI) and at last outside capital. Apparently, the ZIMASSET is an anti-extremist financial strategy concentrating on the workplace of the President and the Cabinet or the aggregate obligation of the bureau serves under the tutelage of the President.

The strategy pursues a detail entrepreneur show like China's improvement plan with the point of engaging the state to work like a benefit driven corporate, thus much accentuation on Private Public Partnership. The ZIMASSET however scares away the Foreign Direct Investment through its 49/51\% deal for the investors. However, it is quite prudent to note that the President Mnangagwa's administration is opening Zimbabwe for business despite the conflicting policy. The importance of Foreign Direct Investment to economic growth remains uncontested [20]. Therefore, Zimbabwe has to attract more of Foreign Direct Investment to ensure economic growth.

\subsubsection{Exclusion of Key Stakeholders}

Apart from the above, Nsingo [21] highlighted that the ZIMASSET excludes key strategic shareholders such as the private sector and Non - Governmental Organizations (NGOs) and Health service providers. Furthermore, Multi-National Companies (MNCs), farmers and commercial service providers like financial institutions among others are also excluded from the policy despite being key. From the information assembled, the analyst noticed that it turns into a mammoth undertaking for the arrangement to get purchase in from such vital partners, making the policy flawed during birth. The legislature needed prompt huge Foreign Direct Investment to "handy solution" the economy as conceived in the ZIMASSET. The administration did not completely connect with partners in drafting the report and this has a deadly impact starting at now.

\subsubsection{Lack of Grass Roots Support}

Besides the exclusion of important stakeholders, the research also noted that grass root support remains rudimentary for the success of a policy. The grass root should not be isolated from the conception, formulation and implementation of policy programmes and plans [22]. Be that as it may, just as predecessor policies since 1980, the ZIMASSET lacked grass root support. Lack of thorough consultation in terms of problem identification and formulation and policy implementation leads to lack of grass root support. Economic policies in Zimbabwe have a history of lack of consultation of important stakeholders and this has been detrimental in causing premature deaths of policies. Introspection into the ZIMASSET reveals conspicuously that the policy was a ZANU PF campaign manifesto which was sneaked into the national policy bank without widespread consultation. It therefore becomes problematic for the citizens to implement a policy which they were never part of in the first instance.

\subsubsection{Poor Monitoring and Evaluation}

More still, the ZIMASSET as a policy was initially going to be monitored by the office of the President and Cabinet through a Result Based Management system [10]. Be that as it may, the ZIMASSET policy faltered due to lack of prudent monitoring and evaluation. The policy was left unattended and it became problematic to achieve the quick wins of the policy. The policy deliverables were almost done clandestinely with no clear track record. According to the Government of Zimbabwe [23], the national monitoring and evaluation was developed to enhance the implementation of the ZIMASSET by providing clear guidelines for the conduct of monitoring and evaluation of the policy. However, the work of this department remained unclear and possibly ineffective. It is within 
his context that lack of monitoring and evaluation of the policy serves as an important challenge to the success of a majority of policies in Zimbabwe.

\subsubsection{Lack of Government Commitment}

The research also categorically stated that government commitment towards policies has been contested lately due to a single or more reasons. It seems as if the government's duty ends with crafting policies which then become orphaned since there is no one to duly monitor them till the end. However, from literature review, the government is presented as the main actor in the policy with a huge role to play hence its commitment is necessary thereof. Commitment on the part of the government can take the form of sourcing funding, monitoring, evaluation, dealing with corruption and other delinquencies that militate against the success of the policy.

In line with the above, respondents argued that the government is no longer committed to policies that ensure our welfare. Its commitment is directed towards the ZANU PF party and it is difficult for us to separate the government from the party and whether the ZIMASSET is from the party or the government. Surely, ZIMASSET has been silent on the requisite needs of people and has been a ZANU PF policy for these five years. To substantiate the above views Masiyakurima [13] highlighted that it has however been difficult to distinguish the party from the government. Therefore, government commitment becomes compromised in this regard.

\section{Conclusion}

Research results conspicuously showed that both the rural and urban population from different walks of walks of life are aware of the existence of economic policies in Zimbabwe especially the ZIMASSET under study. From the respondents, a number of challenges militate against the successful implementation of policies in Zimbabwe. Weak internal policy on one hand and other factors on the other hand, for instance, corruption, sanctions, lack of policy independence, funding, limitedness in Foreign Direct Investment (FDI), lack of monitoring and evaluation among other ills. The research revealed that for there to be economic growth in Zimbabwe internal and external factors should be closely attended to.

The research has demonstrated that most of the economic policies of Zimbabwe are not new but somewhat a perpetuation of those existential before, especially the Land Reform Program among other policies. However, failures of the mother policy will also guarantee resounding failure on the existing and other policies that have a framework in it. Further, success of the previous policy will also mean the same on the part of the new policies especially ZIMASSET.

Policies in Zimbabwe cannot be divorced from party politics and in the vast majority of cases this has failed the implementation of policies. Both rural and urban population, inclusive of youths, civil servants, traditional leadership, NGO's, churches, etc contend that Zimbabwe is a "think tank" of economic policies and its policies are smoothly implemented by other countries because of their goodness. However, a good policy in Zimbabwe is not an end in itself since there is need for funding, close monitoring, and policy education among a multiplicity of pertinent issues. Moreover, proper policy procedure is lacking in the policy landscape of Zimbabwe.

The study delineated on the multiplicity of challenges that are existential in the implementation of economic policies in Zimbabwe. Urban and rural respondents contend that in as much as various economic policies exist, very little has been leveraged to ensure economic growth. The ZIMASSET for instance is not entirely known among the citizens any deeper except the glorification of the acronym. Thus, in as much as it is nearing its expiry date, it has not delivered as of late. Closure of industries in Zimbabwe as a lethal economic problem is serious and the ZIMASSET has not addressed it. This is partly due to so many clusters that strain the annual budget of less than 4.1 billion dollars.

Moreover, Foreign Direct Investment is on its serious decline of which it is key for economic development in Zimbabwe. Respondents acknowledged the government's efforts to indigenize, however, it is debilitating that the Policy scare away Foreign Direct Investment through its $49 \%$ / 51\% deals. Be that as it may, some highlighted the efforts by the President-elect E.D Mnangagwa to revise the regressive dictates of the ZIMASSET policy through opening the country for business.

Further, the Land Reform Program dealt a fair share on Zimbabwe's economy especially manufacturing industries and ultimately leading to food insecurity. Respondents noted that the ZANU $\mathrm{PF}$ cronies who received land together with the few landless peasants were enthusiastic of owning 
vast pieces of lands, however, they lacked the agricultural know how so as to ensure production and food security.

From the research, it was explored that the current ZIMASSET Policy is nothing much than a political manifesto that was sneaked in to be a national policy. This anyway is not sound for a policy for it is already partisan thereby influencing the fulfilment of its stipulations. Availing inputs on a political platform is partisan for a national policy which ought to be unbiased in any case. Centralism of a policy influences its financing from conceivable supporters. The policy document reveals that the ZIMASSET Policy will be under the tutelage of the President and his Cabinet as managers. Furthermore, the research was a declaration that policy failure in Zimbabwe is credited to poor strategy strategies.

From the policy cycle, an appropriate approach has the phases that are inclusive of:

1. problem setting and agenda setting

2. definition

3. reception

4. execution

5. assessment

6. support and upkeep

A large portion of Zimbabwe's internal policies assume a grasshopper's methodology as a few phases are purposefully or accidentally excluded.

The research paper has dealt so well on issues to do with challenges affecting the implementation of policies in Zimbabwe Further, the paper elucidated on the policy making procedures and also the vastness of the 4 clusters of the ZIMASSET Policy.

In as much as the ZIMASSET had some deliverables, they had been limited in scope and it is essential to underline boldly some recommendations that can be put in place to ensure a resounding success on Zimbabwe's policies and how they can contribute to the growth or rather germination of Zimbabwe's buried economy.

- Policy Autonomy

The need to guarantee the self-governance of monetary approaches in Zimbabwe stays focal. From the research done in both country and urban regions of Manicaland Province, the meetings, and polls undisputedly brought up that the policies of Zimbabwe are a greater amount of ZANU PF party strategy members. Considering the ZIMASSET under examination, the diction is demonstrative of a factional arrangement, that is "After the avalanche triumph of ZANU PF party", this shows how divided an expected "national policy" is. Moreover, the Presidential Input Support Schemes for example, have not been benefited on an impartial platform but rather a political one subsequently with such sort of a methodology; the policies in Zimbabwe are bound to fail.

- Clear Policy Procedures

Clear policy techniques are prescribed to guarantee financial advancement in Zimbabwe. Internal policy disappointment in Zimbabwe has been to a great extent attributed to poor policy procedures which result in policies without a reasonable premise. It is exceptionally essential for the policy makers to guarantee that there are:

1. problem identification and agenda setting

2. formulation

3. adoption

4. implementation

5. monitoring

6. assessment

Such religious commitment to the policy procedures featured above ensures policy accomplishment as there will be investment of the subjects in issues affecting them and furthermore energy to actualize such policies.

- Utmost commitment to the policy

As a follow up to the previously mentioned suggestion, it is much fitting to seek after a policy up to the end. The research discoveries demonstrated that in Zimbabwe, there is a propensity of presenting new policies before the expiry of the current policies. A model was drawn from 
the Command Agriculture and Command Fishing, for example, at Marovanyati Dam. Such sort of a methodology is symbol of policy disappointment and an offer to pre - involve individuals' psyches with different undertakings which in a few cases even conflict with the current policy and furthermore prompt policy abortion.

- Adequate funding

It is likewise prescribed that wellsprings of funding are basic to deflect internal policy failures. In as much as a policy can be great, it is nothing but an end in itself as there is serious need to source financing in order to bankroll the policy. Both urbanites and rustic inhabitants over the political, social and religious separation uncovered that the ZIMASSET is failed by its vainglorious methodology. The respondents uncovered that the policy projections require 27 billion dollars versus a yearly spending plan of an effectively under 4.1 billion dollars in this brutal economy. Further, the diamonds intended to bankroll the strategy were deceitfully mined, sold, and drained with a $\$ 15$ billion vanishing. The policy drives off Foreign Direct Investment (FDI) to such an extent that the conceivable wellspring of financing is as of now blocked. Subsequently, there is serious need to source subsidizing in order to fund the bankrolling of internal policies in Zimbabwe.

- Curbing Corruption

The government is recommended to be very serious about corruption if there are hopes of policy success nationally. Corruption is an outcome of inadequate governance and is better defined as the abuse of entrusted authority for illicit gain. Matsheza $(2001 ; 13)$ defined corruption as the misuse of public power or authority for private benefit through bribery, peddling, sometimes extortion, fraud, speed money, embezzlement, and nepotism. The Zimbabwe Anti-Corruption Commission has been having its own flaws hence there is need to revitalize it and ensure that its vigour is restored. Statistics from the World Economic Forum Reveal that \$2.6 trillion is lost each year to corruption globally. The 2015 Perceptions Index reported by Transparency International Corruption Rank accorded Zimbabwe the 150th least corrupt nation out of 175 countries. The lethality of corruption in Zimbabwe is such that there is inhibition of investment since very few would dare to invest or start a new company branch in a corrupt country. Not only does corruption inhibit economic development but social, religious and even political development. Therefore, more energy should be channelled towards curbing corruption in Zimbabwe's parastatals which are focal points for the implementation of policies in Zimbabwe.

- Supporting the Agricultural Sector

Another recommendation lies in the need to motivate farmers through good selling prizes for their produce and also the free availing of inputs. In as much as agriculture is the backbone of the economy of Zimbabwe, it is disheartening to note how the government side-lines and sometimes neglects the farmers. Currently Zimbabwe imports some of its wheat from South Africa and also maize from Zambia. This does not entail that they are no farmers in Zimbabwe. Rural and urban farmers disclosed that the government is actually "mocking" them as they suffer to get inputs and also suffer in selling their maize at Grain Marketing Board, cotton and also tobacco at Boka auction floors. Such an approach by the government demotivates the farmers to the effect that they produce for their own sustainability. It is crucial to note that the agricultural sector is the compass to the economic vessel of Zimbabwe as it unlocks other economic activities, for instance, manufacturing industries which in turn create the much needed employment. All this serves to show that the government is recommended to be serious about the agricultural sector.

\section{References}

[1] V. Sibanda and Makwata, Zimbabwe Post Independence Economic Policies: A Critical Review. National University of Science and Technology. Bulawayo, 2017.

[2] P. Pham, Is there a secret Growth Hormone Added to China's Economy. Forbes: LLC, 2018.

[3] R. Jennings, Bad for Business, China's corruption isn't getting any better despite crackdowns. Forbes. LLC, 2018. 
[4] G. Lange, "Wealth, Natural Capital and Sustainable Development, Contrasting Examples from Botswana and Namibia," Environmental and Resource Economics, vol. 29, no. 3, pp. 257- 83, 2004.

[5] International Monetary Fund, World Economic Outlook Database. United Nations, 2014.

[6] J. Castillo, Sampling Techniques Revised. Oxford. Oxford University Press, 2009.

[7] W. Plosila, "State Science and Technology Based Economic Development," History Trends and Developments and Future Directions, Economic Development. Quarterly, vol. 18, 2004.

[8] J. Kangwari, Why Zimbabwe Policies fails on Implementation. Zimbabwe. Newsday, 2015.

[9] Stanford Encyclopaedia of Philosophy, Social Institutions and Metaphysics Research Lab. Stanford University Press, 2014.

[10] ZIM ASSET, ZIMASSET Document. Zimbabwe. Government Publishers, 2013.

[11] World Law Dictionary Project, Legislative Framework. USA. [12] Share, K. (2016). New Indigenization Framework unveiled. Herald, 2007.

[13] P. Masiyakurima, ZIMASSET a Pie in the Sky. 2016. [Online]. Available: http://thezime conomist.co.zw/2016/12/09. [Accessed: January 2020].

[14] K. A. Elliot, Corruption as an International Policy Problem. Washington DC: Institute for International Economics, 1997.

[15] J. Mujuru, ZIMASSET fails to serve the economy. Daily News, 2014.

[16] P. Shumba, ZIMASSET Scores Big. Zimbabwe. Herald, 2017.

[17] B. C. Mpofu, ZIMASSET Blue Print: Blessing or Curse? Harare. Government Publishers, 2014.

[18] B. Machiva, ZIMASSET a failed economic policy. Harare: Newsday, 2017.

[19] B. Mhlanga, ZANU PF Abusing State Resources. Harare: Newsday, 2018.

[20] F. Ahmet, Importance of Foreign Direct Investment on Economic Development of Transitional Countries. A case of Kosovo. University of Prizen, 2016.

[21] D. Nsingo, Government satisfied with ZIM - ASSET progress. Sunday Times, 2014.

[22] A. Kolawole, "The Role of Grassroots Participation in National Development: Lesson from the Kwara State of Nigeria," Community Development Journal, Oxford University Press, vol. 17, no. 2, 2018.

[23] Government of Zimbabwe, Zimbabwe National Monitoring and Evaluation Policy PDF. Harare: Zimbabwe, 2015. 